\title{
Urgensi Sosialisasi Pendaftaran Ibadah Haji Diusia Muda Sebagai Upaya Pemerintah Menghadapi Waiting List Haji Di Indonesia
}

\author{
Rizki Khairunnisa ${ }^{1 *}$ \\ ${ }^{1}$ Jurusan Manajemen Dakwah, UIN Sunan Kalijaga, Yogyakarta \\ Email:rizkikhairunnisaa@gmail.com
}

\begin{abstract}
ABSTRAK
Haji merupakan salah satu ibadah yang sangat populer atau masyhur bagi seluruh umat muslim di dunia, yaitu sebagai bentuk implementasi rukun Islam yang ke-lima. Di Indonesia sendiri minat masyarakat umat muslim untuk dapat menunaikan ibadah haji selalu mengalami peningkatan dari tahun ke tahun. Hal Ini mengakibatkan waiting list yang terbilang lama yaitu mencapai 41 tahun sehingga mayoritas jemaah haji Indonesia berada pada usia lansia pada saat keberangkatan. Berkaca dari waktu tunggu (waiting list) yang terjadi di Indonesia maka perlu adanya upaya dalam menghadapinya, baik dari pihak pemerintah maupun masyarakat. Tulisan ini membahas tentang upaya pemerintah dalam menghadapi waiting list di Indonesia dengan cara mensosialisasikan pentingnya pendaftaran ibadah haji diusia muda. Upaya sosialisasi dari permerintah tersebut diharapkan dapat menyadarkan masyarakat untuk mempersiapkan pendaftaran ibadah haji diusia muda yang bertujuan mengurangi berbagai risiko pada masa keberangkatan, seperti kondisi kesehatan, usia lanjut, risiko tinggi, dan daya tangkap yang berkurang. Hal tersebut tentunya dapat menganggu proses perjalanan dan pelaksanaan ibadah haji. Metode yang digunakan dalam penulisan ini yaitu deskriptif kualitatif melalui studi literatur, dengan menjabarkan faktor penting dalam pendaftaran ibadah haji diusia muda dan sosialisasi pemerintah terkait urgensi pendaftaran ibadah haji diusia muda sebagai upaya menghadapi waiting list di Indonesia.
\end{abstract}

Kata Kunci : Sosialisasi, Haji Diusia Muda, Upaya Pemerintah, dan Waiting list. 


\section{ABSTRACT}

Hajj is one of the most popular or famous forms of worship for all Muslims in the world, namely as a form of implementation of the fifth pillar of Islam. In Indonesia, the interest of the Muslim community to be able to carry out the pilgrimage has always increased from year to year. This resulted in a fairly long waiting list, reaching 41 years, so that the Indonesian Hajj was at an elderly age when he disappeared. Reflecting on the waiting time (waiting list) that occurs in Indonesia, it is necessary to deal with it, both from the government and society. This paper discusses the government's efforts in dealing with waiting lists in Indonesia by socializing the importance of registering the Hajj pilgrimage at a young age. The socialization efforts of the government are expected to be able to make the public aware of the registration of Hajj pilgrimage registration at a young age which aims to reduce various risks during the validity period, such as health conditions, old age, high risk, and reduced catching power. This of course can disrupt the travel process and the implementation of the pilgrimage. The method used in this study is descriptive qualitative through literature studies, by explaining important factors in the registration of youth worship and related government socialization urging the registration of youth worship as an effort to face waiting lists in Indonesia.

Keywords: Socialization, Young Hajj, Government Efforts, and Wait List

\section{PENDAHULUAN}

Haji merupakan salah satu ibadah yang sangat masyhur atau populer bagi umat muslim diseluruh dunia sebagai bentuk implementasi rukun Islam yang ke-lima. Menurut Imam Syafi'i ibadah haji dilaksanakan dengan menyengaja mengunjungi atau berziarah ke Baitullah Makkah untuk beribadah kepada Allah SWT, yang dimulai pada 1 syawal hingga 10 Dzulhijjah

Ibadah haji harus mengutamakan kesanggupan atau kemampuan (istitha'ah) sebagai syarat bagi mereka yang ingin melaksanakan rukun Islam yang ke-lima. Secara singkat, syarat kesanggupan atau kemampuan itu diuraikan dalam bentuk kemampuan finansial dan kesehatan jasmani, sehingga seseorang dapat menanggung beban berat perjalanan ibadah haji yang sering dianalogikan sebagai jihad kecil (Al Habash,2016:2)

Syarat kesanggupan tersebut sebagaimana Allah SWT berfirman didalam Al-Qur'an , sebagai berikut : 


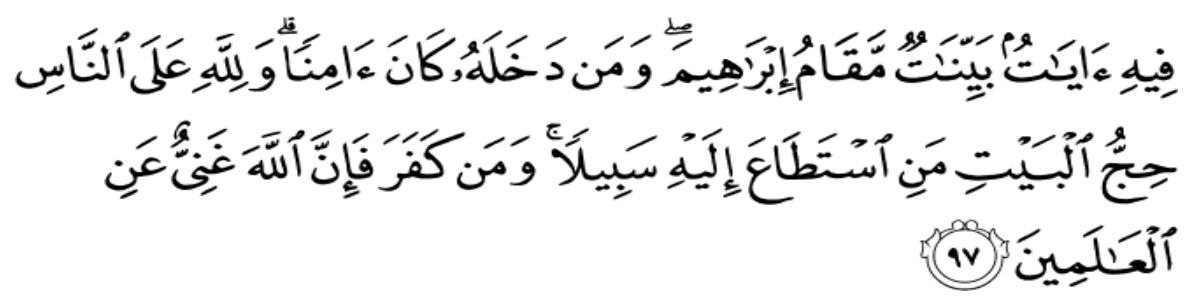

Artinya : "Padanya terdapat tanda-tanda yang nyata, (di antaranya) maqam Ibrahim; barangsiapa memasukinya (Baitullah itu) menjadi amanlah dia; mengerjakan haji adalah kewajiban manusia terhadap Allah, yaitu (bagi) orang yang sanggup mengadakan perjalanan ke Baitullah. Barangsiapa mengingkari (kewajiban haji), maka sesungguhnya Allah Maha Kaya (tidak memerlukan sesuatu) dari semesta alam" (QS. Ali Imran : 97)

(Terjemahan diambil pada link, https://tafsirq.com/3-ali-imran/ayat-97)

"Mampu" atau "istitha'ah" bidang kesehatan menurut pedoman teknis pembinaan Kesehatan jamaah haji (204:1) adalah mampu menunaikan ibadah haji ditinjau dari jasmani yang sehat dan kuat agar dapat melaksanakan perjalanan dan mudah melakukan proses ibadah haji, berakal sehat dan memiliki kesiapan mental untuk menunaikan ibadah haji di Arab Saudi, serta aman bagi keluarga yang ditinggalkannya.

Meski demikian, Pada setiap tahunnya minat umat muslim diseluruh dunia untuk melaksanakan ibadah haji selalu meningkat terkhusus umat muslim Indonesia. Hal tersebut dapat dilihat dari data dilaman databoks yang menyatakan, sejak tahun 2016, jumlah jemaah Indonesia selalu meningkat. Pada tahun 2018 jemaah haji Indonesia mencapai 203.350 jiwa, naik 0,13\% dari tahun sebelumnya yang sebesar 203.070. peningkatan tertinggi terjadi pada tahun 2017 yang mencapai $31,5 \%$. Peningkatan ininseiring dengan penambahan kuota haji menjadi 221.000 orang. https://databoks.katadata.co.id/datapublish/2020/02/28/berapajumlah-jemaah-haji-di-indonesia

Peningkatan minat umat muslim Indonesia untuk berangkat ibadah haji membuat meningkatnya pula jumlah pendaftar ibadah haji. Akibatnya daftar tunggu (waiting list) di Indonesia semakin lama. Menurut data yang telah dirilis Kementerian Agama pada tahun 2019 daftar tunggu pemberangkatan ibadah 
haji sudah mencapai 41 tahun. Daftar tunggu terlama tersebut ada di Kabupaten Bantaeng, Provinsi Sulawesi Selatan. Dalam web resmi Kementerian Agama yang ditulis tim redaksi pada tahun 2014, pengertian waiting list itu sendiri merupakan daftar tunggu jemaah haji yang akan diberangkatkan ke Arab Saudi. (Kementerian Agama, "Waiting List", https://haji.kemenag.go.id/v3/ )

Berkaca dari daftar tunggu yang tergolong sangat lama dan usia jemaah haji yang pada saat mendaftar rata-rata berada diusia 35-50 tahun, maka akan banyak kemungkinan terjadi pada masa penantian hingga waktu keberangkatan. Kemungkinan tersebut antara lain; meninggal pada waktu penantian, fisik yang mulai lemah serta jemaah dengan risiko tinggi (risti) karena jemaah sudah memasuki usia lanjut ketika waktu keberangkatan. Padahal pada dasarnya ibadah haji dilakukan bagi meraka yang tidak hanya mampu secara finansial saja tetapi juga mampu secara fisik. Harimurti, 2012:220-254)

Sebagai dampak dari waktu tunggu haji yang begitu lama, maka penting bagi pemerintah untuk mensosialisasikan terkait pendaftaran haji diusia muda, agar ketika waktu keberangkatan belum memasuki usia lanjut dan mengurangi risiko tinggi. Pendaftaran haji diusia muda berkisar pada usia 12-15 tahun, sehingga pada usia 35-50 tahun jemaah dapat menunaikan ibadah haji dengan kondisi yang baik dan semakin menambah kualitas perjalanan ibadah haji. Namun pada kenyataanya sangat disayangkan pemerintah masih kurang sosialisasi terkait pendaftaran haji diusia muda. Alhasil masih sangat banyak jemaah haji Indonesia sudah memasuki usia lanjut ketika menunaikan ibadah haji. (https://www.republika.co.id/berita/jurnal-haji/berita-jurnal-haji/18/08/13/ pddpxp366-pemerintah-minim-sosialisasi-)

Berdasarkan pemaparan masalah yang telah dipaparkan diatas, penulis melakukan kajian melalui studi literatur dari berbagai sumber. Tujuannya untuk mengetahui upaya yang telah dilakukan pemerintah Indonesia untuk mensosialisasikan pentingnya pendaftaran haji diusia muda yang disebabkan waktu tunggu (waiting list) yang begitu lama. Oleh karena itu, penulis mengadakan studi literatur terhadap masalah tersebut dengan judul "Urgensi Sosialisasi Pendaftaran Ibadah Haji Diusia Muda Sebagai Upaya Pemerintah Menghadapi Waiting List Haji Di Indonesia."

Rumusan permasalahan dalam penulisan ini adalah bagaimana sosialisasi pemerintah kepada masyarakat terkait pentingnya mendaftar haji diusia muda dalam menghadapi waiting list haji di Indonesia? 
Sebuah karya ilmiah yang terbit pada tahun 2016, Nida Farhanah mempublikasikan penelitiannya dengan judul "Problematika Waiting List Dalam Penyelenggaraan Ibadah Haji Di Indonesia”. Dalam penelitian tersebut Nida menyatakan ada tiga faktor penyebab terjadinya daftar tunggu. Pertama pada aspek yuridis, yakni belum adanya landasan yuridis yang kuat terkait dengan kebijakan yang seharusnya dijalankan oleh pemerintah. Jikapun ada, pemerintah belum sepenuhnya menjalankan kebijakan tersebut dengan tegas. Kedua pada aspek filosofis yang disebabkan oleh belum lurusnya kesadaran beragama dari calon jemaah haji untuk menunaikan ibadah yang suci ini. Ketiga pada aspek sosiologis yang disebabkan adanya perluasan area thawaf dan rehabilitasi Masjidil Haram yang berimbas pada pengurangan kuota haji, meningkatnya ekonomi umat Islam dan biaya haji yang terjangkau, mudahnya mendapatkan porsi haji, kurangnya rasa toleransi para pengulang haji, dan adanya arisan haji.

Berdasarkan penelitian diatas, penulis telah mencoba mencari karya ilmiah yang relevan dengan penelitian yang akan dilakukan. Namun, masih sangat minim sehingga penulis hanya dapat memaparkan satu kajian pustaka yang memiliki relevansi. Dari penelitian diatas dapat disimpulkan berbagai faktor menjadi penyebab membengkaknya atau lamanya waiting list haji di Indonesia. Dengan demikian penelitian seputar pentingnya sosialisi pendaftaran haji diusia muda sebagai upaya pemerintah dalam menghadapi waiting list haji di Indonesia sangat relevan. Karena upaya tersebut sangat penting bagi jemaah haji guna mencapai tujuan ibadah haji.

\section{LANDASAN TEORITIS}

Menurut Depkes RI (2005) Sosialisasi merupakan penyebarluasan informasi (program, kebijakan dan peraturan) dari satu pihak (pemiliki program, kebijakan dan peraturan) kepada pihak-pihak lain (aparat, masyarakat yang terkena program dan masyarakat umum). (Aprilia,2009:61) Dalam Wikipedia (2020) Sosialisasi adalah sebuah proses penanaman atau transfer kebiasaan atau nilai dan aturan dari satu generasi ke generasi lain dalam sebuah kelompok atau masyarakat.

Sedangkan menurut Sugiayana (2008), Sosialisasi merupakan aktivitas 
komunikasi yang bertujuan untuk menciptakan perubahan pengetahuan, sikap menta dan perilaku khalayak sasaran terhadap ide pembaharuan (inovasi) yang ditawarkan. Sugiyana (2008) juga berpendapat bahwa sosialisasi adalah pengenalan dan penyebarluasan program kepada masyarakat dan aparat yang menjadi sasaran program serta kepada pihk-pihak lain yang berkepentingan atau menjadi mitra kerja.

Ibadah haji adalah rukun Islam yang ke lima. rukun tersebut menetapkan bahwa bagi setiap muslim yang mampu wajib untuk melaksanakannya, sekali seumur hidup. Mengerjakan haji ialah mengerjakan beberapa amal tertentu di Makkah dan dibeberapa tempat diluar kota Makkah dalam bulan Dzhulhidjah. Mengerjakan haji itu hukumnya fardhu'ain bagi umat Islam yang akil-baligh dan mampu sekali dalam seumur hidup serta sunnat mengerjakannya berualangulang.(Farhanah, 2016:4)

Haji secara etimologi berasal dari bahasa Arab yaitu : al-hajju yang berarti: al-qashdu yaitu menyengaja atau menuju, bermaksud, berniat pergi atau berniat untuk mendatangi seseorang yang dipandang mulia, yang dimaksud dengan berniat dalam pengertian ini ialah berniat untuk melakukan sesuatu yang baik ditempat tertentu, karena tempat itu dipandang mulia atau terhormat. Karena itu, termasuk dalam pengertian umum haji adalah apabila seseorang mengunjungi orang lain yang dipandang mulia atau terhormat. Kemudian dalam pengertian terminologi, haji mempunyai arti orang yang berziarah ke Makkah untuk menunaikan rukun Islam yang ke lima (Suryadi, 2011:47-48).

Pada Kamus Besar Bahasa Indonesia atau KBBI, kata upaya berarti usaha, ikhtiar, untuk mencapai suatu maksud, memecahkan persoalan, mencari jalan keluar. Berdasarkan makna dalam KBBI itu, dapat disimpulkan bahwa kata upaya memiliki kesamaan arti dengan kata usaha, dan demikian dengan kata ikhtiar, dan upaya yang dilakukan dalam rangka mencapai suatu maksud, memecahkan persoalan, mencari jalan keluar.

Pengertian upaya menurut Tim Penyusun Departemen Pendidikan Nasional (2008:1787), "Upaya adalah usaha, akal atau ikhtiar untuk mencapai suatu maksud, memecahkan suatu persoalan, mencari jalan keluar, dan lain sebagainya".

Menurut Poerwadar Minta (1991:574), "Upaya adalah usaha untuk menyampaikan maksud, akan dan iktisar. Upaya merupakan segala sesuatu yang bersifat mengusahakan terhadap sesuatu hal supaya dapat lebih berdaya guna 
dan berhasil guna sesuai dengan maksud, tujuan dan fungsi serta manfaat suatu hal tersebut dilaksanakan".

Menurut Moh. Kusnardi dan Bintan R. Saragi (2008:122), "Pemerintah adalah alat bagi negara dalam menyelenggarakan sesgala kepentingan rakyatnya dan merupakan alat juga, dalam mewujudkan tujuan yang sudah direncanakan".

Menurut Bayu Surya Ningrat (1992:10) "Pemerintah adalah perbuatan atau cara urusan pemerintah misalnya yang adil, pemerintah yang demokratis, pemerintah yang diktator".

Dari definisi upaya dan pemerintah diatas, maka dapat disimpulkan definisi upaya pemerintah merupakan usaha atau ikhtiar yang dilakukan oleh perangkat negara yang kita sebut dengan pemerintah dalam mencapai tujuan yang telah direncanakan. Upaya yang akan dilakukan pemerintah dalam penulisan ini yaitu mensosialisasikan pentingnya mendaftar haji diusia muda sebagai respon semakin lamanya waiting list haji di Indonesia.

$W$ aiting list (daftar tunggu) adalah daftar tunggu calon jemaah haji yang telah mendaftar dan mendapatkan nomor porsi, akan tetapi belum bisa berangkat pada tahun saat mendaftar, dan mereka terpaksa menunggu keberangkatan untuk menunaikan ibadah haji, disebabkan jumlah yang mendaftar lebih banyak dari yang berangkat haji pada tahun berjalan. (Japeri, 2013:3)

\section{HASIL DAN PEMBAHASAN}

\section{Urgensi Mendaftar Haji di Usia Muda}

Seperti yang kita ketahui, ibadah haji menjadi penyempurna rukun Islam. Namun selama ini, ibadah haji banyak dijalankan ketika jemaah haji sudah memasuki usia lanjut. Hal tersebut disebabkan karena jemaah haji mendaftar ketika berusia 35-45 tahun, ditambah dengan waiting list di Indonesia yang telah mencapai 41 tahun pada tahun 2019. Berikut beberapa faktor pentingya mendaftar Haji di Usia Muda:

a) Faktor Kesehatan. Ibadah haji merupakan ibadah yang sangat membutuhkan stamina fit atau mengutamakan fisik, dan mayoritas kebugaran tersebut terdapat pada mereka yang masih diusia muda. Pasalnya akan banyak kegiatan untuk melaksanakan rukun haji yang ditempuh dengan jarak yang tidak 
dekat dan cuaca yang berbeda di Indonesia. Oleh karena itu, akan berkualitas kegitan rukun haji yang akan dilaksanakan jika berangkat pada usia muda. Selain itu, faktor kesehatan juga menjadi salah satu syarat calon jemaah haji dapat menunaikan ibadah haji.

b).Faktor Kognitif. Pada rangkaian perjalanan ibadah haji, jemaah haji akan mengikuti berbagai bimbingan dan pelatihan untuk mempersiapkan keberangkatannya agar dapat menjadi jeamaah haji mandiri. Dalam proses bimbingan manasik jemaah haji akan diberikan berbagai materi dan arahan terkait rukun dan sunnah haji, sehingga dibutuhkan pemahan yang cepat karena waktu bimbingan yang terbatas. Meskipun usia tidak mempengaruhi tingkat kecerdasan, tetapi daya ingat dan tingkat pemahaman lebih mudah diterima oleh meraka jemaah haji yang belum memasuki usia lanjut. Oleh karena itu, mendaftar haji diusia muda sangat penting untuk memperlancar perjalanan ibadah haji.

c). Jemaah Risti (risiko tinggi) Risti adalah suatu kondisi dimana jemaah haji memiliki potensi lebih besar mengalami sakit dibanding jemaah haji biasa. Kondisi risti terjadi pada jemaah haji yang memasuki usia 60 tahun ke atas. Menurut pernyataan Kepala Pusat Kesehatan (Kapuskes) Haji, 2019, "Sebesar $62 \%$ dari jemaah haji tahun 1440 H/2019 M mempunyai kategori risti. Kondisi risti pada jemaah akan sangat menganggu perjalan ibadah haji”. (https://nasional.sindonews.com/berita/1413036/15/kapuskes-haji-jelaskanperbedaan-jamaah-risti-dan- ) Oleh karena itu, penting adanya kesadaran diri maupun orangtua untuk mempersiapkan pendaftaran haji diusia muda untuk buah hati.

\section{Upaya Pemerintah}

Usia dalam menjalankan ibadah haji akan mempengaruhi dan memberi kualiatas dari prosesi kegiatan ibadah haji itu sendiri. Idealnya seseorang melaksanakan ibadah haji diusia antara 40-45 tahun, karena seperti yang kita ketahui perjalanan ibadah haji sangat membutuhkan stamina yang fit. Selain harus adanya kesadaran pada diri sendiri, pihak lain dalam hal ini yaitu pemerintah juga harus ada terobosan atau usaha untuk mewujudkan idealitas usia jemaah haji guna mengurangi berbagai risiko khususnya risiko tinggi. Karena waktu tunggu 
(waiting list) pada penyelenggaraan ibadah haji di Indonesia sudah mencapai 41 tahun yaitu di Kabupaten Bantaeng, Provinsi Sulawesi Selatan.

Salah satu upaya yang dilakukan pemerintah dalam menghadapi waiting list haji di Indonesia yaitu dengan mensosialisasikan pendaftaran ibadah haji diusia muda, yang bertujuan untuk meminimalisir angka jemaah haji dalam kategori jemaah risiko tinggi. Namun, menurut Syam Resfiandi pada tahun 2018 pemerintah masih sangat minim dalam mensosialisasikan pendaftaran haji diusia muda. Alhasil rata-rata jemaah haji pada waktu keberangkatan telah memasuki usia dengan risiko tinggi .(https://ihram.co.id/berita/ pddpxp366/ pemerintahminimsosialisasipendaftaranhajidiusiamuda)

Dalam Peraturan Menteri Agama (PMA) Nomor 13 Tahun 2018 usia minimal mendaftar haji yaitu 12 tahun. Peraturan tersebut salah terobosan pemerintah dalam menghadapi waiting list haji di Indonesia. Namun, peraturan tersebut masih jarang diketahui masyarakat, sehingga pemerintah perlu mensosialisasikan agar masyarakat dapat mempersiapkan lebih dini dan mendaftar haji diusi muda.

Begitu pentingnya mensosialisasikan pendaftaran haji diusia muda untuk menyadarkan masyarakat berbagai risiko yang akan terjadi jika menunaikan ibadah haji dalam usia lanjut. Pentingnya mensosialisasikan pendaftaran ibadah haji juga dilakukan pemerintah karena waiting list haji di Indonesia sudah cukup memanjang.

\section{PENUTUP}

Pendaftaran ibadah haji diusia muda akan memberikan dampak positif pada jemaah haji. Mulai dari persiapan yang lebih matang hingga kualiatas ibadah haji yang dilakukan di Tanah Suci akan berjalan dengan maksimal, tanpa terkendala faktor stamina atau fisik, pemahaman materi dan jemaah risiko tinggi.

Namun, pendaftaran ibadah haji diusia muda yaitu yang mulai diusia 12 tahun ternyata masih sangat jarang diketahui masyarakat, sehingga rata-rata jemaah haji Indonesia saat waktu keberangkatan sudah memasuki usia lanjut dan berisiko tinggi. Hal tersebut terjadi karna minimnya sosialisasi dari pemerintah dan membekaknya waiting list haji di Indonesia. 


\section{DAFTAR PUSTAKA}

Al Habash, A. (2016). Manajemen Pelayanan Kesehatan Jemaah Haji Pada Musim Haji 2016 Di Embarkasi Jakarta Pondok Gede, Skripsi.UIN Syarif Hidayatullah, Jakarta. Aprilia, Yesie. (2009). Analisis Sosialisasi Program Inisiasi Menyusu Dini dan ASI Eksklusif Kepada Bidan Di Kabupaten Klaten, Tesis. Universitas Diponegoro, Semarang.

Databoks, Badan Pusat Statistik, Berapa Jumlah Jemaah Haji di Indonesia ? bttps:/ / databoks.katadata.co.id/datapublish/2020/02/28/berapa-jumlah-jemaabbaji-di-indonesia, 29 April 2020.

Farhanah, N. (2016). Problematika Waiting List Dalam Penyelenggaraan Ibadah Haji Di Indonesia, Palangkaraya. Jurnal Studi Agama dan Masyarakat.

Harimurti, H. 2012. Waiting List Nasional Upaya Memperkecil Kemudharatan Masa Penantian Keberangkatan Haji dalam buku Dinamika dan Perspektif Haji Indonesia. Jakarta,ISBN.

https://ihram.co.id/berita/pddpxp366/pemerintahminimsosialisasipendaftaran hajidiusiamuda ,10

Japeri, Pengaruh Kuota Terhadap Daftar Tunggu Naik Haji Di Kota Padang, Padang, Jurnal Ekonomi dan Bisnis Islam.

Kementerian Agama, "Waiting List", https://haji.kemenag.go.id/v3/, 18 Februari 2020.

Marsyaf, Muh. Iqbal. SINDONEWS, Kapuskes Haji Jelaskan Perbedaan Jamaah Risti dan Tak Istitha'ah Kesehatan, https:/ / nasional.sindonews.com/berita/1413036/15/kapuskes-hajijelaskan-perbedaan-jamaah-risti-dan-tak-istithaah-kesehatan , 10 Mei 2020. Mei 2020.

Muwardati, A. M. Kompasiana, Alasan Mengapa Pentingnya Mempersiapkan Haji Sedini Mungkin, https://www.kompasiana.com/adindamutia/5c37352e6ddcae18cf784ec2/ inilah-alasan-mengapa- mempersiapkan-haji-harus-sedini-mungkin-2 ,10 Mei 2020.

PT. ALJHIJAZ INDOWISATA. Daftar Tunggu Ibadah Haji 2019, https://alhijazindowisatapt.com/daftar-tunggu-haji/, 18 Februari 2020.

Republika.co.id, Pemerintah Minim Sosialisasi Pendaftaran Haji di Usia Muda, https://www.republika.co.id/berita/jurnal-haji/berita-jurnal- 
Urgensi Sosialisasi Pendaftaran Ibadah Haji Diusia Muda Sebagai Upaya Pemerintah Menghadapi Waiting List Haji Di

haji/18/08/13/pddpxp366-pemerintah-minim-sosialisasi-pendaftaranhaji-di-usia-muda, 18 Februari 2020.

Republika.co.id, Pemerintah Minim Sosialisasi Pendaftaran Haji Diusia Muda 
R.Khoirunnisa 